\title{
Decision Making System for Determining the Hepatitis Food Criteria using Analytical Hierarchy Process Method
}

\author{
Ade Irma Wati1, Satria Abadi, M. Ilayaraja, Wahidah Hashim, Larisa N. Gorina
}

\begin{abstract}
Hepatitis is a kind of inflammation which attacks the body's organ known as liver. Hepatitis itself is divided into commonly known types namely Hepatitis $A, B$, and $C$. however, there exist other types of hepatitis called $D, E, G$ which are not familiar. The understanding of patients regarding hepatitis is an obstacle in healing. The thing that is needed is to regulate diet and avoid foods that are prohibited (high sodium, high saturated fat, high sugar, and high protein). Hepatitis sufferers must pay attention to food patterns, must control foods consumed daily, must consume food with low salt, low saturated fat, low in sugar, and low in protein to reduce the risk of not worsening the condition of people with hepatitis. The decision making system determines the hepatitis food criterion using 5 criteria's, namely the presence of high sodium, high saturated fat, high protein, high sugar, and high iron. While the Analytical Hierarchy Process (AHP) method is a decision making model which defines the multi-factor problems or complex multi criteria into a hierarchy. With hierarchy, a complex problem could be partitioned into smaller groups which are then ordered in a hierarchy to arrange the problem in a structural and systematic way.
\end{abstract}

\section{Keywords: AHP, Decision making, hepatitis food.}

\section{INTRODUCTION}

A t present in the world there are an estimated 350 million sufferers (carier) HBsAg and 220 million (78\%) of them are in Asia, including Indonesia. Based on HBsAg examination in the blood donor group in Indonesia the prevalence of Hepatitis ranges from 2.50 to $36.17 \%$, it is necessary to have special treatment to stop the rate of spread of hepatitis. Efforts to reduce hepatitis sufferers need to be done by all layers in various ways. Because in addition to its high prevalence, hepatitis viruses can cause post-acute problems and can even occur cirroshis hepatitis and primary hepatocellular carcinoma. Ten percent of hepatitis virus infections will become chronic and $20 \%$ of patients with chronic hepatitis within 25 years of contracting will experience cirroshis hepatitis and hepatosellular carcinoma (hepatoma). The possibility of being chronic is higher if the infection occurs at

Revised Manuscript Received on December 15, 2019.

* Correspondence Author

Ade Irma Wati, Department of Information System, STMIK Pringsewu, Lampung, Indonesia.

Satria Abadi, Department of Information System, STMIK Pringsewu, Lampung, Indonesia.

M. Ilayaraja*, School of Computing, Kalasalingam Academy of Research and Education, Krishnankoil, India.

Wahidah Hashim, Institute of Informatics and Computing Energy, Universiti Tenaga Nasional, Malaysia.
Larisa N. Gorina, Togliatti State University, Russia.

the age of the toddler where the immune response has not developed fully. [1]

Hepatitis is a kind of inflammation which attacks the body's organ known as liver. Hepatitis itself is divided into commonly known types namely Hepatitis A, B, and C. however, there exist other types of hepatitis called D, E, G which are not familiar [2].

The understanding of patients regarding hepatitis is an obstacle in healing. The thing that is needed is to regulate diet and avoid prohibited (high sodium, high saturated fat, high sugar, and high protein). Hepatitis sufferers must pay attention to food patterns, it can control foods consumed daily, foods that are low salt, low saturated fat, low sugar, and low protein to reduce the risk of not worsening the condition of people with hepatitis [3]

Seeing these problems, this study was shown to solve the problem by making a decision making system to determine hepatitis food criterion using the analytical hierarchy process (AHP) method, it is applied to determine the right food criterion based on criteria and predetermined weight. This method was chosen because it was able to select the best alternative from all alternatives. So that from a food criterion decision making system is expected to help those with hepatitis.

\section{LITERATURE REVIEW/THEORETICAL BASE}

\section{A. Healthy Food}

Healthy food is food that contains balanced nutrition needed by human body by concocting various types of balanced foods, so that all nutritional need of the body is fulfilled and be able to be felt physically and mentally. (Mahardikaningtyas, Ali Nugroho, \& Hartono, 2013). [4]

\section{B. Hepatitis}

Hepatitis is a liver disorder in the form of inflammation (cells) of the liver. This inflammation is characterized by increasing liver enzyme levels. This increase is caused by a disorder or damage to liver membrane. There are two factors that cause infection factors and non-infectious factors. Factors that cause infection include hepatitis viruses and bacteria. In addition to Hepatitis A, B, C, D, E, and G viruses there are still many other viruses that have the potential to cause hepatitis such as adenoviruses, CMV, Herpes simplex, HIV, rubella, varicella and others. 
While the bacteria that cause hepatitis include, for example, Salmonella typhi, Salmonella paratyphi, tuberculosis, leptosvera. Non-infectious factors for example because of drugs. Certain Obet can interfere with liver function and cause hepatitis (Dalimartha, 2008). [5]

\section{Decision Support System}

It has the capability to offer problem solving and communication skills for problems with semi-structured and unstructured conditions. It can be employed to take decisions in semi-structured scenarios and unstructured scenarios, where there is no information related to decision making (Kusrini, 2007). [6]

\section{Analytical Hierarchy Process}

AHP is a kind of decision making methods introduced by Dr. Thomas L. Satty, a mathematician from the University of Pittsburg, United States in the early 1970s. The basic thinking of the AHP method is the process of forming a numerical score which ranks every decision alternatives depending upon how the alternative should be matched with the criterion of decision makers (Saaty, 1999). [7]

\section{E. Fuzzy Multiple Attibute Decision Making}

According to [8-12], Fuzzy Multiple Attribute Decision Making (FMADM) is a method utilized to identify the optimum alternatives from total criteria. The core of Fuzzy MADM is to identify the weights for every criterion, which will then be a ranking process that will choose alternatives.

There are some methods used to solve MADM :

1) Simple Additive Weight (SAW)

2) Weighted Product (WP)

3) Analytical Heirarchy Process (AHP)

4) Technique for order preference by similitary to ideal solution (TOPSIS)

5) Elimination et choix tradujisant la realite (ELECTRE) [13]

\section{RESEARCH METHODOLOGY}

\section{A. Research Flowchart}

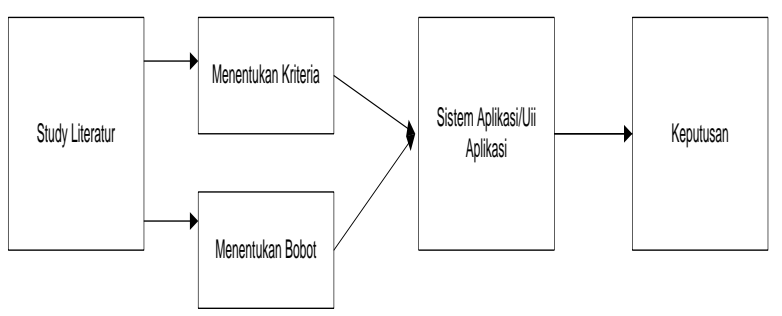

Fig. 1.Flowchart

- $\quad$ Literature Study : In this stage, it was collected 18 papers and information about hepatitis food criteria

- Determining criterion: In this stage, determining selected criterion to find criterion score in selecting weight score.

- Determining Weight Score: In this stage, determining weight score is searching criterion score.

- Application System/Application Test: In this stage it was performed application test to determine a decision.

\section{B. AHP Method}

Basically, procedure or stages in AHP method consists of :

a. Define problem and determine expected solution

b. Determine element priority

c. Synthesis

d. Measure consistency

e. Measure Consistency index (CI) with formula : $\mathrm{CI}=\left(\lambda_{\max }-\mathrm{k}\right) / \mathrm{k}-1$

Where $\mathrm{k}$ represents the number of elements

f. Measure Consistency Ratio (CR) with formula : $\mathrm{CR}=\mathrm{CI} / \mathrm{RI}$

where $\mathrm{CI}$ and RC represents the Consistency Index and Consistency Consistency respectively [14].

Table-I: Quantitative Scale in AHP Method

\begin{tabular}{|c|c|c|}
\hline $\begin{array}{l}\text { Interest } \\
\text { intensit } \\
y \\
\end{array}$ & Definition & Explanation \\
\hline 1 & $\begin{array}{l}\text { Every element is } \\
\text { essential }\end{array}$ & $\begin{array}{l}\text { both elements have same } \\
\text { influence to the purpose }\end{array}$ \\
\hline 3 & $\begin{array}{l}\text { An element is } \\
\text { somewhat highly } \\
\text { essential } \\
\text { compared to } \\
\text { others }\end{array}$ & $\begin{array}{l}\text { Experience and judgment } \\
\text { support one element instead of } \\
\text { other }\end{array}$ \\
\hline 5 & $\begin{array}{l}\text { An element is } \\
\text { essential } \\
\text { compared to } \\
\text { others }\end{array}$ & $\begin{array}{l}\text { Experience and assessment } \\
\text { strongly support one element } \\
\text { compared to others }\end{array}$ \\
\hline 7 & $\begin{array}{l}\text { An element is } \\
\text { highly essential } \\
\text { compared to } \\
\text { others }\end{array}$ & $\begin{array}{l}\text { One strong element is } \\
\text { supported and the domain is } \\
\text { seen in practice }\end{array}$ \\
\hline 9 & $\begin{array}{l}\text { One element is } \\
\text { absolutely } \\
\text { important than } \\
\text { the other } \\
\text { elements }\end{array}$ & $\begin{array}{l}\text { Evidence that supports one } \\
\text { element to another element } \\
\text { holds higher degree of } \\
\text { affirmation that might } \\
\text { strengthen }\end{array}$ \\
\hline $2,3,4,6$ & $\begin{array}{l}\text { Scores between } 2 \\
\text { consideration are } \\
\text { close }\end{array}$ & $\begin{array}{l}\text { This score is given if there is a } \\
\text { compromise between } 2 \text { choices }\end{array}$ \\
\hline Opposite & \multicolumn{2}{|c|}{$\begin{array}{l}\text { If activity } 1 \text { receives a number compared to activity } \mathrm{J} \text {, } \\
\text { then } \mathrm{J} \text { has the opposite score compared to I }\end{array}$} \\
\hline
\end{tabular}

1) Research criterion

As for some criteria in this research are :

$\mathrm{C} 1=$ high natrium

$\mathrm{C} 2$ = high saturated fat

$\mathrm{C} 3=$ high protein

$\mathrm{C} 4=$ high sugar

$\mathrm{C} 5=$ high iron

2) Weight criterion

In this research, there are weight criteria in determining hepatitis food namely.

Eight Criterion Table

\begin{tabular}{|l|l|}
\hline $\begin{array}{c}\text { criterio } \\
\mathbf{n}\end{array}$ & \multicolumn{1}{|c|}{ Weight criterion } \\
\hline $\mathrm{C} 1$ & 25 \\
\hline $\mathrm{C} 2$ & 35 \\
\hline $\mathrm{C} 3$ & 20 \\
\hline $\mathrm{C} 4$ & 20 \\
\hline & 100 \\
\hline
\end{tabular}


Tested Alternative

$$
\begin{aligned}
& \text { A1 }=\text { fruit } \\
& \text { A2 }=\text { vegetable } \\
& \text { A3 }=\text { meat } \\
& \text { A4 }=\text { peanut }
\end{aligned}
$$

\section{DISCUSSION}

\section{A. Manual Test}

Decision support system determines hepatitis food criterion using 5 criteria's namely: high sodium, high saturated fat, high protein, high sugar, high iron. The stages in the AHP method are:

1. Define problem and determine expected solution.

2. Make hierarchy structure began with general purpose, scored criterion and alternative

Fig. 2.AHP Hierarchy Structure

After performing this, after making the AHP hierarchy structure, the subsequent level of application development is to determine alternate weights by compiling a paired matrix for alternative of every criterion.

Alternative weight for criterion Input recommended criterion data in paired form.

Table-II: Paired comparison matrix criterion

\begin{tabular}{|l|l|l|l|l|l|}
\hline Criterion & \multicolumn{1}{|c|}{ C1 } & \multicolumn{1}{|c|}{ C2 } & \multicolumn{1}{|c|}{ C3 } & \multicolumn{1}{|c|}{ C4 } & C5 \\
\hline A1 & 2 & 3 & 4 & 5 & 6 \\
\hline A2 & $2 / 3$ & 2 & 3 & 4 & 5 \\
\hline A3 & $2 / 4$ & $3 / 4$ & 2 & 3 & 4 \\
\hline A4 & $2 / 5$ & $3 / 5$ & $4 / 5$ & 2 & 3 \\
\hline A5 & $2 / 6$ & $3 / 6$ & $4 / 6$ & $5 / 6$ & 2 \\
\hline
\end{tabular}

The above matrix data is modified from fraction to decimal form.

Table-III: Results of Paired comparison of semi-criterion paired weighting

\begin{tabular}{|l|l|l|l|l|l|}
\hline criterion & \multicolumn{1}{|c|}{ C1 } & \multicolumn{1}{|c|}{ C2 } & \multicolumn{1}{|c|}{ C3 } & \multicolumn{1}{c|}{ C4 } & \multicolumn{1}{c|}{ C5 } \\
\hline C1 & 2 & 3 & 4 & 5 & 6 \\
\hline C2 & 0,67 & 2 & 3 & 4 & 5 \\
\hline C3 & 0,5 & 0,75 & 2 & 3 & 4 \\
\hline C4 & 0,4 & 0,6 & 0,8 & 2 & 3 \\
\hline C5 & 0,3 & 0,5 & 0,67 & 0,83 & 2 \\
\hline Total & 3,87 & 6,85 & 10,47 & 14,83 & 20 \\
\hline
\end{tabular}

After determining temporary total values / weights, every individual element present in the above cell is divided by the individual column totals, for instance, to fill the second column and the second row was $(\mathrm{C} 1: \Sigma$ weight $\mathrm{C} 1) \rightarrow(1.00$ :

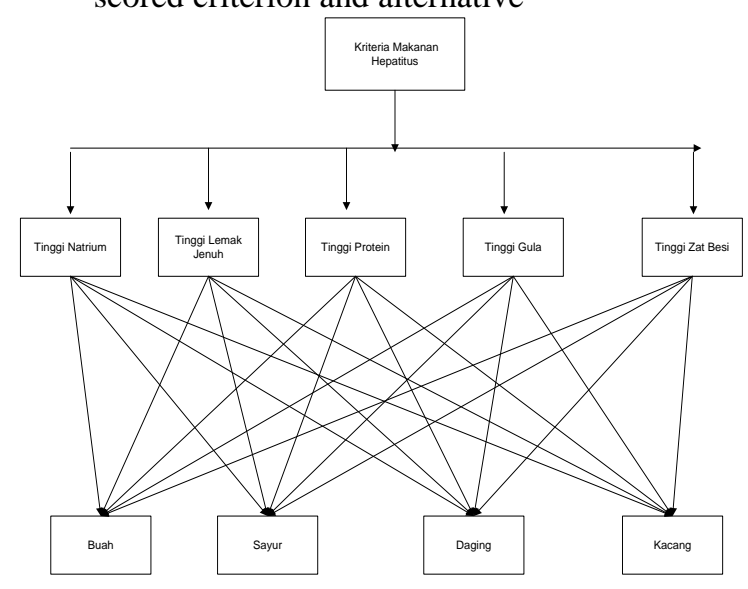

$2.45)=0.4082$ (utilize the similar approach to fill remaining columns) to obtain equivalent results.

Table-IV: Comparison Results of semi-criterion paired weighting alternative

\begin{tabular}{|l|l|l|l|l|l|l|}
\hline Criterion & C1 & \multicolumn{1}{|c|}{ C2 } & \multicolumn{1}{|c|}{ C3 } & \multicolumn{1}{|c|}{ C4 } & \multicolumn{1}{|c|}{ C5 } & TOTAL \\
\hline C1 & 2,2 & 0,4 & 0,3 & 0,3 & 0,3 & 3,5 \\
& 988 & 379 & 820 & 371 & - & 558 \\
\hline C2 & 0,1 & 0,2 & 0,2 & 0,2 & 0,25 & 0,95 \\
& 731 & 919 & 865 & 697 & - & 212 \\
\hline C3 & 0,1 & 0,1 & 0,1 & 0,2 & 0,2 & 0,7 \\
& 291 & 094 & 910 & 022 & - & 317 \\
\hline C4 & 0,1 & 0,0 & 0,0 & 0,1 & 0,15 & 0,35 \\
& 0,33 & 875 & 764 & 348 & - & 020 \\
\hline C5 & 0,0 & 0,0 & 0,0 & 0,0 & 0,1 & 0,1 \\
& 775 & 729 & 639 & 559 & - & 702 \\
\hline
\end{tabular}

After the total results of each row were known, then calculate the alternative priority score to average criterion score with the formula of Total results of the comparison divided by the number of alternatives. The example to fill priority criterion $\mathrm{C} 1$ was ( $\Sigma$ the result of the comparison: $\Sigma$ criterion) $\rightarrow(3,55558 / 5)=0.71116$ (use the same method to fill in the other columns) so that results are found in the table below.

Table-V: Priority results based on criterion

\begin{tabular}{|l|l|l|}
\hline \multicolumn{1}{|c|}{ Criterion } & \multicolumn{1}{|c|}{$\begin{array}{c}\text { Criterion } \\
\text { priority }\end{array}$} & \multicolumn{1}{|c|}{ Ranking } \\
\hline C1 & 0,71116 & II \\
\hline C2 & 0,190424 & I \\
\hline C3 & 0,14634 & III \\
\hline C4 & 0,07004 & IV \\
\hline C5 & 0,03404 & V \\
\hline
\end{tabular}

After determining criterion priority has been completed, the next step is to determine the priority of each alternative, namely by inputting the comparison value of each alternative.

Table-VI: Comparison of high natrium paired criterion (C1)

\begin{tabular}{|l|l|l|l|l|}
\hline \multicolumn{1}{|c|}{$\mathbf{C 1}$} & \multicolumn{1}{|c|}{$\mathbf{A 1}$} & \multicolumn{1}{|c|}{$\mathbf{A 2}$} & \multicolumn{1}{|c|}{$\mathbf{A 3}$} & \multicolumn{1}{|c|}{$\mathbf{A 4}$} \\
\hline A1 & 2 & 0,5 & 3 & 0,33 \\
\hline A2 & 4 & 2 & 6 & 0,66 \\
\hline A3 & 0,67 & 0,16 & 2 & 0,11 \\
\hline A4 & 6 & 1,51 & 9,09 & 2 \\
\hline Total & 12,67 & 3,81 & 20,09 & 3,1 \\
\hline
\end{tabular}

Next, create a normalization table for high sodium criterion by dividing the score of each matrix box by the total column.

Table-VII: Normalization of high natrium criterion

\begin{tabular}{|c|c|c|c|c|c|}
\hline $\mathbf{C 1}$ & $\mathbf{A 1}$ & $\mathbf{A 2}$ & $\mathbf{A 3}$ & $\mathbf{A 4}$ & TOTAL \\
\hline A1 & 0,15 & 0,15 & 0,15 & 0,15 & 0,60 \\
\hline A2 & 0,31 & 0,31 & 0,31 & 0,31 & 1.24 \\
\hline A3 & 0,05 & 0,05 & 0,05 & 0,05 & 0,2 \\
\hline A4 & 0,47 & 0,47 & 0,47 & 0,47 & 1,88 \\
\hline
\end{tabular}

Then, calculate the total rows to be divided by alternatives to find priority scores. The results of the calculation of high sodium priority are as follows.

Published By:

Blue Eyes Intelligence Engineering 
Table-VIII: The results of the calculation of high sodium priority are as follows

\begin{tabular}{|l|l|l|}
\hline \multicolumn{1}{|c|}{ Alternative } & \multicolumn{1}{|c|}{$\begin{array}{c}\text { Criterion } \\
\text { priority }\end{array}$} & \multicolumn{1}{|c|}{ Ranking } \\
\hline A1 & 0,15 & III \\
\hline A2 & 0,31 & II \\
\hline A3 & 0,05 & IV \\
\hline A4 & 0,47 & I \\
\hline
\end{tabular}

Table-IX: Paired comparison of high saturated fat criterion (C2)

\begin{tabular}{|l|l|l|l|l|}
\hline C2 & A1 & A2 & A3 & A4 \\
\hline A1 & 2 & 0,33 & 3 & 0,25 \\
\hline A2 & 6 & 2 & 9 & 0,75 \\
\hline A3 & 0,66 & 0,11 & 2 & 0,08 \\
\hline A4 & 8 & 1.32 & 12 & 2 \\
\hline Total & 16,66 & 3,76 & 26 & 3,08 \\
\hline
\end{tabular}

Then, a normalization table is created for high saturated fat criterion by dividing the value of every matrix box by the total column.

Table-X: Normalization of high saturated criterion

\begin{tabular}{|l|l|l|l|l|l|}
\hline C2 & A1 & A2 & A3 & A4 & TOTAL \\
\hline A1 & 0,12 & 0,12 & 0,12 & 0,12 & 0,48 \\
\hline A2 & 0,36 & 0,36 & 0.36 & 0,36 & 1,44 \\
\hline A3 & 0,03 & 0,03 & 0,03 & 0,03 & 0,12 \\
\hline A4 & 0,48 & 0,48 & 0,48 & 0,48 & 1,92 \\
\hline
\end{tabular}

Then, calculate the total rows to be divided by alternatives to determine the priority score. The results of the calculation of high saturated fat priority are as follows

Table-XI: Priority of high saturated fat

\begin{tabular}{|l|l|l|}
\hline Alternative & Criterion priority & Ranking \\
\hline A1 & 0,12 & III \\
\hline A2 & 0,36 & II \\
\hline A3 & 0,03 & IV \\
\hline A4 & 0,48 & I \\
\hline
\end{tabular}

Table-XII: Paired comparison of high protein (C3).

\begin{tabular}{|l|l|l|l|l|}
\hline C3 & A1 & A2 & A3 & A4 \\
\hline A1 & 2 & 3 & 4 & 0,5 \\
\hline A2 & 0,66 & 2 & 1,33 & 0,16 \\
\hline A3 & 0,5 & 0,75 & 2 & 0,12 \\
\hline A4 & 4 & 6 & 8 & 2 \\
\hline Total & 7,16 & 11,75 & 15,33 & 2,78 \\
\hline
\end{tabular}

Then, a normalization table is created for high protein criterion by dividing the value of every matrix box by the total column.

Table-XIII: Normalization of high protein criterion

\begin{tabular}{|l|l|l|l|l|l|}
\hline C3 & A1 & A2 & A3 & A4 & TOTAL \\
\hline A1 & 0,27 & 0,27 & 0,27 & 0,27 & 1,08 \\
\hline A2 & 0,09 & 0,09 & 0,09 & 0,09 & 0,36 \\
\hline A3 & 0,06 & 0,06 & 0,06 & 0,06 & 0,24 \\
\hline A4 & 0,55 & 0,55 & 0,55 & 0,55 & 2,2 \\
\hline
\end{tabular}

Then, calculate the total rows to be divided by alternatives to find priority values. The results of high protein priority calculations are as follows
Table-XIV: High protein priority

\begin{tabular}{|l|l|l|}
\hline Alternative & $\begin{array}{l}\text { Criterion } \\
\text { priority }\end{array}$ & Ranking \\
\hline A1 & 0,27 & II \\
\hline A2 & 0,09 & III \\
\hline A3 & 0,06 & IV \\
\hline A4 & 0,55 & I \\
\hline
\end{tabular}

Table-XV: Paired comparison of high sugar criterion (C4).

\begin{tabular}{|l|l|l|l|l|}
\hline C4 & A1 & A2 & A3 & A4 \\
\hline A1 & 2 & 4 & 0,2 & 5 \\
\hline A2 & 0,5 & 2 & 0,05 & 1,25 \\
\hline A3 & 10 & 20 & 2 & 25 \\
\hline A4 & 0,4 & 0,8 & 0,04 & 2 \\
\hline Total & 12,9 & 26,8 & 2,29 & 33,25 \\
\hline
\end{tabular}

Then, a normalization table is created high sugar criterion by dividing the value of every matrix box by the total column.

Table-XVI: Normalization of high sugar

\begin{tabular}{|l|l|l|l|l|l|}
\hline C4 & A1 & A2 & A3 & A4 & TOTAL \\
\hline A1 & 0,15 & 0,15 & 0.15 & 0,15 & 0,6 \\
\hline A2 & 0.03 & 0,03 & 0,03 & 0,03 & 0,12 \\
\hline A3 & 0.77 & 0,77 & 0,77 & 0,77 & 3,08 \\
\hline A4 & 0,03 & 0,03 & 0,03 & 0,03 & 0,12 \\
\hline
\end{tabular}

Then, calculate the total rows to be divided by alternatives to determine the priority values. The results of the calculation of high sugar priority are as follows

Table-XVII: Priority of high sugar

\begin{tabular}{|l|l|l|}
\hline Alternative & $\begin{array}{l}\text { Criterion } \\
\text { priority }\end{array}$ & Rangking \\
\hline A1 & 0,15 & II \\
\hline A2 & 0,03 & III \\
\hline A3 & 0,77 & I \\
\hline A4 & 0,03 & IV \\
\hline
\end{tabular}

Table-XVIII: Paired comparison of high iron criterion (C5).

\begin{tabular}{|l|l|l|l|l|}
\hline C5 & A1 & A2 & A3 & A4 \\
\hline A1 & 2 & 1 & 0,5 & 0,33 \\
\hline A2 & 2 & 2 & 0,5 & 0,33 \\
\hline A3 & 4 & 2 & 2 & 0,66 \\
\hline A4 & 6 & 3 & 1,51 & 2 \\
\hline Total & 14 & 8 & 4,51 & 3,32 \\
\hline
\end{tabular}

Then, a normalization table is created for high iron criterion by dividing the value of every matrix box by the total column.

Table-XIX: Normalization of high iron

\begin{tabular}{|l|l|l|l|l|l|}
\hline C5 & A1 & A2 & A3 & A4 & TOTAL \\
\hline A1 & 0,14 & 0,14 & 0,14 & 0,14 & 0,56 \\
\hline A2 & 0,14 & 0,14 & 0,14 & 0,14 & 0,56 \\
\hline A3 & 0,28 & 0,28 & 0,28 & 0,28 & 1,12 \\
\hline A4 & 0,42 & 0,42 & 0,42 & 0,42 & 1,68 \\
\hline
\end{tabular}

Then, calculate the total rows to be divided by alternatives to determine priority score. The results of the calculation of high iron priority are as follows

Published By: 
Table-XX: High iron priority

\begin{tabular}{|l|l|l|}
\hline Alternative & $\begin{array}{l}\text { Criterion } \\
\text { priority }\end{array}$ & Ranking \\
\hline A1 & 0,14 & IV \\
\hline A2 & 0,14 & III \\
\hline A3 & 0,28 & II \\
\hline A4 & 0,42 & I \\
\hline
\end{tabular}

And the final stage is to compute the best alternative in the decision-making system to determine hepatitis food criteria and the final calculation results as follows.

Table-XXI: Final Result of Calculation

\begin{tabular}{|l|l|l|l|l|l|}
\hline $\begin{array}{l}\text { Criterion/ } \\
\text { Alternative }\end{array}$ & C1 & C2 & C3 & C4 & C5 \\
\hline Weight & 0,2 & 0,2 & 0,2 & 0,15 & 0,15 \\
\hline A1 & 0,15 & 0,12 & 0,27 & 0,15 & 0,14 \\
\hline A2 & 0,31 & 0,36 & 0,09 & 0,03 & 0,14 \\
\hline A3 & 0,05 & 0,03 & 0,06 & 0,77 & 0,28 \\
\hline A4 & 0,47 & 0,48 & 0,55 & 0,03 & 0,42 \\
\hline
\end{tabular}

\section{B. Calculation Results}

The final results are calculated by determining the weight score multiplied by alternative priorities.

$\mathrm{A} 1=(0,2 * 0,15)+(0,2 * 0,12)+(0,2 * 0,27)+(0,15 * 0,15)+$ $(0,15 * 0,14)$

$=0,03+0,024+0,054+0,0225+0,021$

$=0,1515$

$=15 \%$

A2 $=(0,2 * 0,31)+(0,2 * 0,36)+(0,2 * 0,09)+(0,15 * 0,03)+$ $(0,15 * 0,14)$

$=0,062+0,072+0,018+0,0045+0,021$

$=0,1775$

$=18 \%$

$\mathrm{A} 3=(0,2 * 0,05)+(0,2 * 0,03)+(0,2 * 0,06)+(0,15 * 0,77)+$ $(0,15 * 0,28)$

$=0,01+0,006+0,012+0,1155+0,042$

$=0,1855$

$=19 \%$

$\mathrm{A} 4=(0,2 * 0,47)+(0,2 * 0,48)+(0,2 * 0,55)+(0,15 * 0,03)+$ $(0,15 * 0,42)$

$=0,094+0,096+0,11+0,0045+0,063$

$=0,3675$

$=37 \%$

Table-XXII: Calculation result

\begin{tabular}{|l|l|l|l|l|l|}
\hline Criterion & C1 & C2 & C3 & C4 & C5 \\
\hline Weight & $\mathbf{0 . 2}$ & $\mathbf{0 . 2}$ & $\mathbf{0 . 2}$ & $\mathbf{0 . 1 5}$ & $\mathbf{0 . 1 5}$ \\
\hline A1 & 0.15 & 0.12 & 0.27 & 0.15 & 0.14 \\
\hline A2 & 0.31 & 0.36 & 0.09 & 0.03 & 0.14 \\
\hline A3 & 0.05 & 0.03 & 0.06 & 0.77 & 0.28 \\
\hline A4 & 0.47 & 0.48 & 0.55 & 0.03 & 0.42 \\
\hline
\end{tabular}

Table-XXIII: Alternative score and criterion

\begin{tabular}{|l|l|l|l|l|l|l|}
\hline $\begin{array}{l}\text { Criteri } \\
\text { on }\end{array}$ & C1 & C2 & C3 & C4 & C5 & result \\
\hline
\end{tabular}

\begin{tabular}{|l|l|l|l|l|l|l|} 
A1 & 0.03 & 0.024 & 0.054 & 0.0225 & 0.021 & 0.1515 \\
\hline A2 & 0.062 & 0.072 & 0.018 & 0.0045 & 0.021 & 0.1775 \\
\hline A3 & 0.01 & 0.006 & 0.012 & 0.1155 & 0.042 & 0.1855 \\
\hline A4 & 0.094 & 0.096 & 0.11 & 0.0045 & 0.063 & 0.3675 \\
\hline
\end{tabular}

Table-XXIV: The results of criterion calculation and weight score.

\begin{tabular}{|l|l|l|l|}
\hline Alternative & & Hasil & Rangking \\
\hline A1 & 0.1515 & $16 \%$ & 4 \\
\hline A2 & 0.1775 & $18 \%$ & 3 \\
\hline A3 & 0.1855 & $19 \%$ & 2 \\
\hline A4 & 0.3675 & $37 \%$ & 1 \\
\hline
\end{tabular}

\section{Analysis}

By observing the computation results takes place and supported by predetermined criterion, it is known that the alternative determining of the most superior hepatitis criterion was A4 with the highest value of 0.3675 or $37 \%$ so that it can be said that A4 (beans) was an option which should not be given to hepatitis.

\section{Application System/ Application Test}

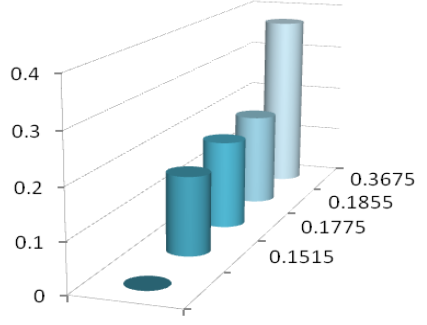

Fig. 3.Final Results Graphic

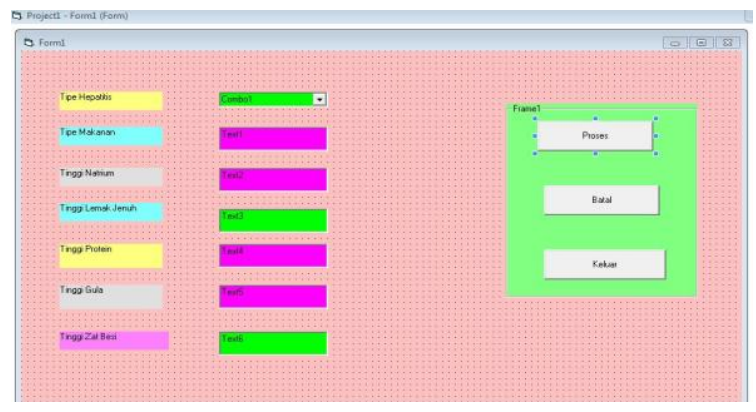

Fig. 4.Input Data

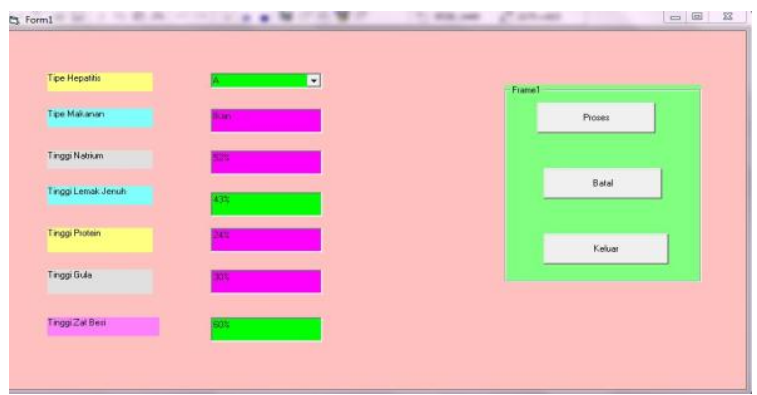

Fig. 5.Output Data 1

Published By:

Blue Eyes Intelligence Engineering 


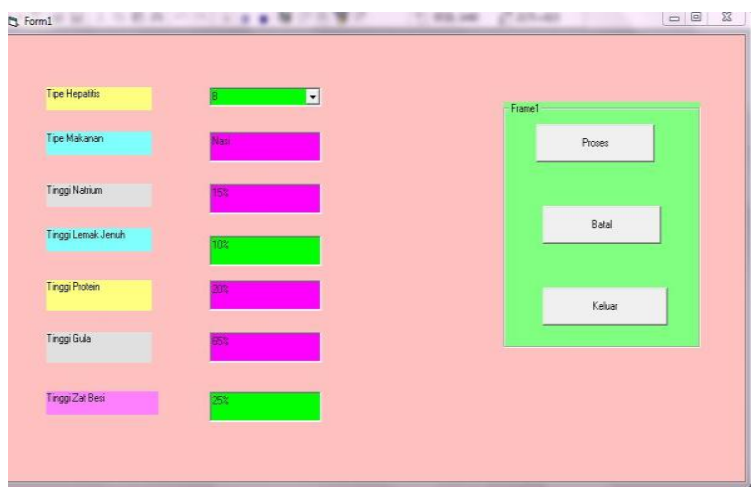

Fig. 6.Output Data 2

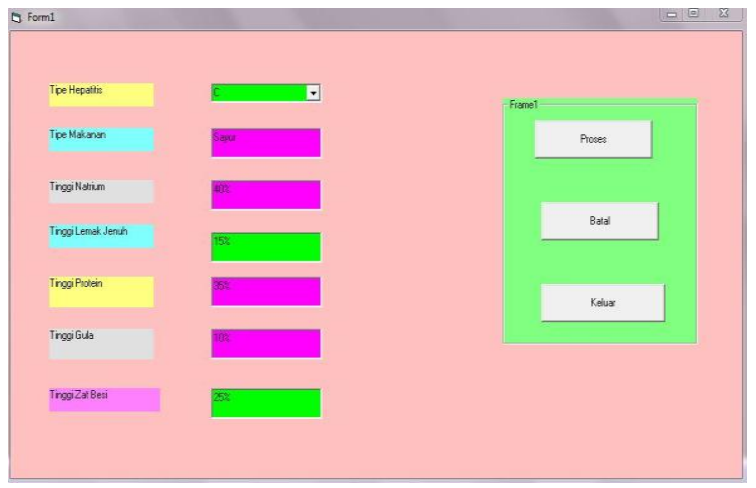

Fig. 7.Output Data 2

\section{CONCLUSION AND SUGGESTIONS}

\section{A. Conclusion}

From the results of testing the system developed using the Analytical Hierarchy Process model it can be concluded that the decision making system by the use of FMADM determines hepatitis food criterion was $\mathrm{A} 1=15 \% \mathrm{~A} 2=18 \%$ $\mathrm{A} 3=19 \%$ A $4=37 \%$. From the results of the calculation of the following alternative score, the highest value was A4 = $37 \%$.

Decision Making System Model Determined Food Criteria Hepatitis used 5 criteria, namely food with high sodium, high saturated fat, high protein, high sugar, and high iron.

\section{B. Suggestion}

As a part of future work, the presented model can be extended to a web based application which will be useful for real time analysis.

\section{REFERENCES}

[1] Ramadhani, R.A., Helilintar, R. and Rochana, S., 2017. Perancangan Sistem Diagonosa Penyakit Hepatitis Menggunakan Metode Knn. ILKOM Jurnal Ilmiah, 9(2), pp.145-152.

[2] Shankar, K., 2017. Prediction of most risk factors in hepatitis disease using apriori algorithm. Research Journal of Pharmaceutical Biological and Chemical Sciences, 8(5), pp.477-484.

[3] Suparno, H.A.O., Lantang, O.A. and Lumenta, A.S., 2016. Sistem Pendukung Keputusan Pemilihan Menu Bagi Penderita Hipertensi. Jurnal Teknik Informatika, 8(1).

[4] Prihatin, T., 2018. IMPLEMENTASI METODE SIMPLE ADDITIVE WEIGHTING DALAM PENENTUAN SUSU UHT TERBAIK UNTUK ANAK BALITA. Jurnal Teknik Komputer, 4(2), pp.1-6.

[5] Surabaya, S., Rancang Bangun Aplikasi Diagnosis Penyakit Hepatitis Menggunakan. pp. 1-11.
[6] Sucipto, H., 2016. Sistem Pendukung Keputusan Penentuan Jurusan Sekolah Menengah Atas Dengan Metode SAW. Sisfotenika, 6(2), pp.146-157.

[7] Saaty, T.L., 1999, August. Fundamentals of the analytic network process. In Proceedings of the 5th international symposium on the analytic hierarchy process (pp. 12-14)

[8] Chang, D.Y., 1996. Applications of the extent analysis method on fuzzy AHP. European journal of operational research,95(3), pp.649-655.

[9] Kahraman, C., Cebeci, U. and Ulukan, Z., 2003. Multi-criteria supplier selection using fuzzy AHP. Logistics information management, 16(6), pp.382-394

[10] Leung, L.C. and Cao, D., 2000. On consistency and ranking of alternatives in fuzzy AHP. European Journal of Operational Research, 124(1), pp.102-113.

[11] Kutlu, A.C. and Ekmekçioğlu, M., 2012. Fuzzy failure modes and effects analysis by using fuzzy TOPSIS-based fuzzy AHP. Expert Systems with Applications, 39(1), pp.61-67.

[12] Sun, C.C., 2010. A performance evaluation model by integrating fuzzy AHP and fuzzy TOPSIS methods. Expert systems with applications, 37(12), pp.7745-7754.

[13] J. Sistem, I. Fakultas, I. Komputer, and U. Sriwijaya, "No Title," vol. 3 , no. 1, pp. 286-293, 2011.

[14] Destari, R.A., 2017, November. PENENTUAN SUSU BAY TERBAIK DENGAN AHP. In Seminar Nasional Informatika (SNIf) (Vol. 1, No. 1, pp. 581-586).

[15] Nugraha, R., Abdillah, G. and Ilyas, R., 2018. SISTEM PENDUKUNG KEPUTUSAN PENENTUAN DESA TERBAIK DI KABUPATEN CIANJUR MENGGUNAKAN METODE ANALYTIC HIERARCHY PROCESS DAN WEIGHTED PRODUCT. SEMNASTEKNOMEDIA ONLINE, 6(1), pp.2-8.

\section{AUTHORS PROFILE}

Ade Irma Wati, Department of Information System, STMIK Pringsewu, Lampung, Indonesia.

Satria Abadi, Department of Information System, STMIK Pringsewu, Lampung, Indonesia.

M. Ilayaraja, School of Computing, Kalasalingam Academy of Research and Education, Krishnankoil, India.

Wahidah Hashim, Institute of Informatics and Computing Energy, Universiti Tenaga Nasional, Malaysia.

Larisa N. Gorina, Togliatti State University, Russia 